\title{
TREATMENT OF EXPERIMENTAL PORTAL VEIN THROMBOSIS WITH STREPTOKINASE
}

\author{
DENEYSEL VENA PORTA TROMBOZUNUN \\ STREPTOKİNAZ ILE TEDAVISI
}

\author{
Tarik ÇA ĞA \\ Firdevs GƯRER \\ Orhan YURTSEVER \\ Bekir YAŞAR
}

\section{SUMMARY}

In this experimental study. 24 rats (Mus. Norvegius Albinos) were used of which 12 were in the control group, and the other 12 in the therapeutic group. In the control group, portal vein thrombosis was created. By venous statis, and histological examinations were performed on the liver specimens, and liver function tests were also acquired for this group. In the therapeutic group, low dose streptokinase-3000 units $(0.003 \mathrm{cc})$ was infused through the portal vein at which venous thrombosis had been produced experimentally. All the rats were sacrificed on the 7 th postoperative day and histological liver examinations and biochemical studies were performed. According to the results there were no evidence of liver ischemia following the use of streptokinase.

(Key Words: Liver ischemia, Plasminogene Activator)

\section{ÖZET}

Bu deneysel çalışmada, 24 sıçan (Mus. Norvegius Albunos). 12'si kontrol, diğer 12'si ise tedavi grubu olmak üzere iki ayrı gruba ayrıldı. Kontrol grubundaki sıçanlarda, vena porta staz yöntemiyle trombüs oluşturuldu ve trombüs sonrası histolojik karaciğer incelemeleri yapıldı ve karaciğer fonksiyon testlerine bakild1. Tedavi grubunda ise, aynı yöntemle trombüs oluşturulduktan sonra, intraportal yoldan düşük doz streptokinaz 3000 ünite $(0.003 \mathrm{cc})$ verildi. Tedavi grubundaki sıçanlar postoperatif 7. günde öldürülerek, postmortem histolojik ve biyokimyasal incelemeler yapıldı. Alınan sonuçlara göre tedavi sonrası karaciğer iskemisine rastlanmad1.

(Anahtar Sözcükler: Karaciğer iskemisi, Plazminojen Aktivatörü)

Department of General Surgery

(Doç.Dr.B Yaşar, Doç.Dr.T Çağa, Dr.O Yurtsever)

Department of Mistology (Doç.Dr.F Gürer)

Osmangazi University, Faculty of Medicine,

Eskişehir, TURKIYE

Reprints : Doç.Dr.T Çağa 
In the present time, the diagnosis and treatment of acute thromboembolies occuring at the arterial side of vital organs is still a great problem. In such conditions it is becoming a necessity to use thrombolytic agents as a choice of treatment $(1,2)$ Streptokinase (SK) is a plasminogene activator, with a molecular weight of 46000 dal. synthesized by beta-hemolytic streptococci and cannot be inhibited by the enzyme antiplasmin $(1,2,3)$.

SK effect is much more pronounced if it is administered directly into the vessels involved. In this experimental study, we applied low-dose SK though the portal vein, at which we had created a thrombus previously.

\section{MATERIALS AND METHODS}

In this experimental study, 24 rats (Mus. Norvegius Albinos), 2 months of age with a mean body weight of 200 grams, were used. Sex of the rats were not taken into account. Rats were maintained in an animal care facility and were allowed free access to standard rat chow and water. General animal care and experiments conformed to all Institutional Animal Care and Use Commitee guidelines. Food but not water was withdrown 12 hours before all animal protocols and no specific measures were taken for their feeding following the experiment. Anesthesia was managed by ether. The rats were separated into two groups.

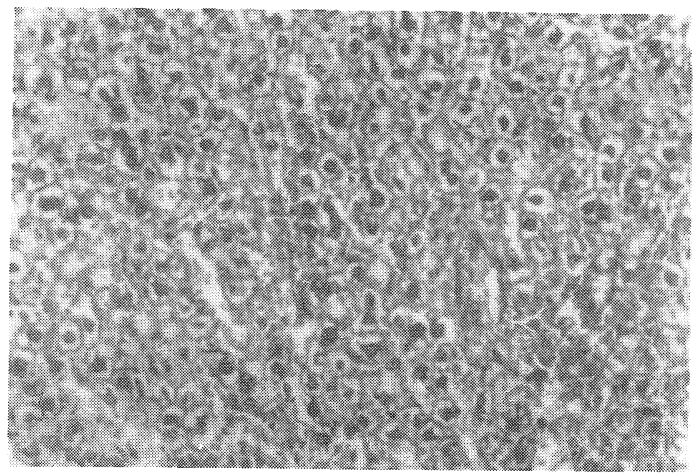

Picture 1 : In control group, vacuolar degeneratio and hyperemias as severe looking as sinusoidal telangiectasias in hepatocytes. H.E. $\times 64$

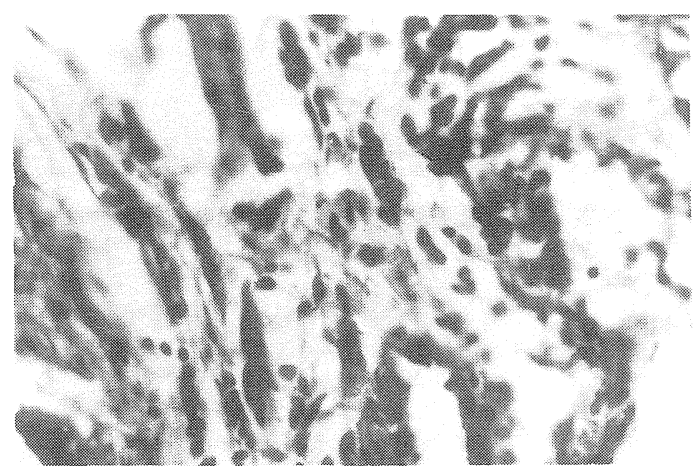

Picture 2 : In control group, disturbed epithelium by cellular infiltration of dominantly eosinophils, at porta hepatis (-) H.E. $\times 128$.

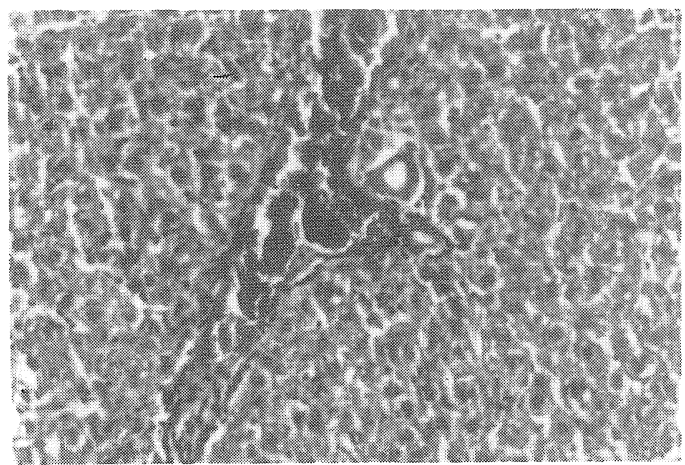

Picture 3 : In control group, venous dilitation of portal spaces (-) and degenerative changes in hepatocytes. H.E. $\times 64$

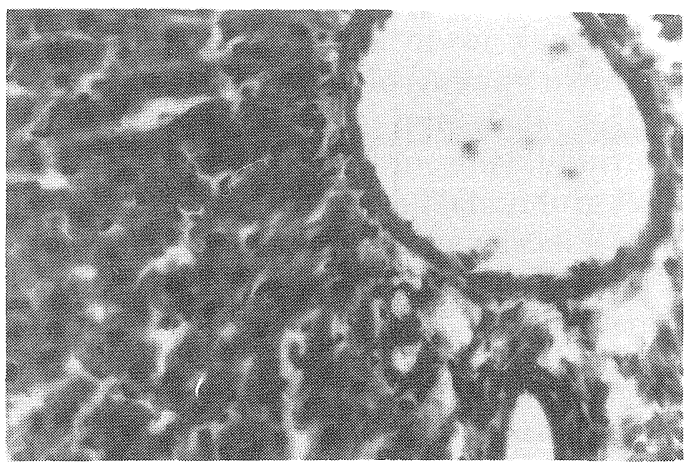

Picture $4:$ In thepareutic group normal pattern of hepotocytes regression of vacuolar degeneration and conestion. H.E. $\times 128$. 


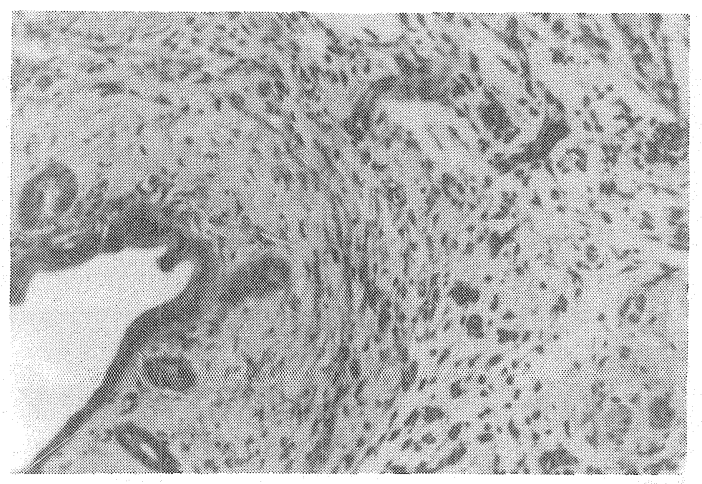

Picture 5: In therapeutic group, normal pattern of hepatocytes at porta hepatis. H.E. × 64 .

Group 1 : This is the control group ( $n=12$ ) following laparotomy with median incision. $V$. porta was prepared without any trauma. By means of two silk sutures, $v$. porta was hanged on at two different points, one is proximal to the Porta Hepatis and the other one is more distally, for $30 \mathrm{~min}$. By that time, thrombus had arised macroscopicaly, and obvious ischemic changes were noticed in the liver paranchimal tissue. After that, the liver was taken off for the histological examinations and was fixed by $10 \%$ formalin solution, at the same time blood samples were drawn for liver function tests.

Group 2: This is the therapeutic group $(n=12)$ with the median laparotomic incision described above, thrombus was created in Venae Porta. In this group also, $30 \mathrm{~min}$. of ischemia was produced and then $3000 \mathrm{u}(0.003$ cc) SK (Kabikinase-Kabi) was infused into the portal vein, then after hemostasis the abdominal wall was closed with 2/0 ethicon silk sutures. The rats were sacrificed by the 7th postoperative day, the liver was taken off for histological examination and blood samples for liver function tests were drawn as well.

\section{RESULTS}

In the therapeutic group, all the rats could survive for seven postoperative days. The Figures 1,2,3 drawn below show the results collected from the control and thera
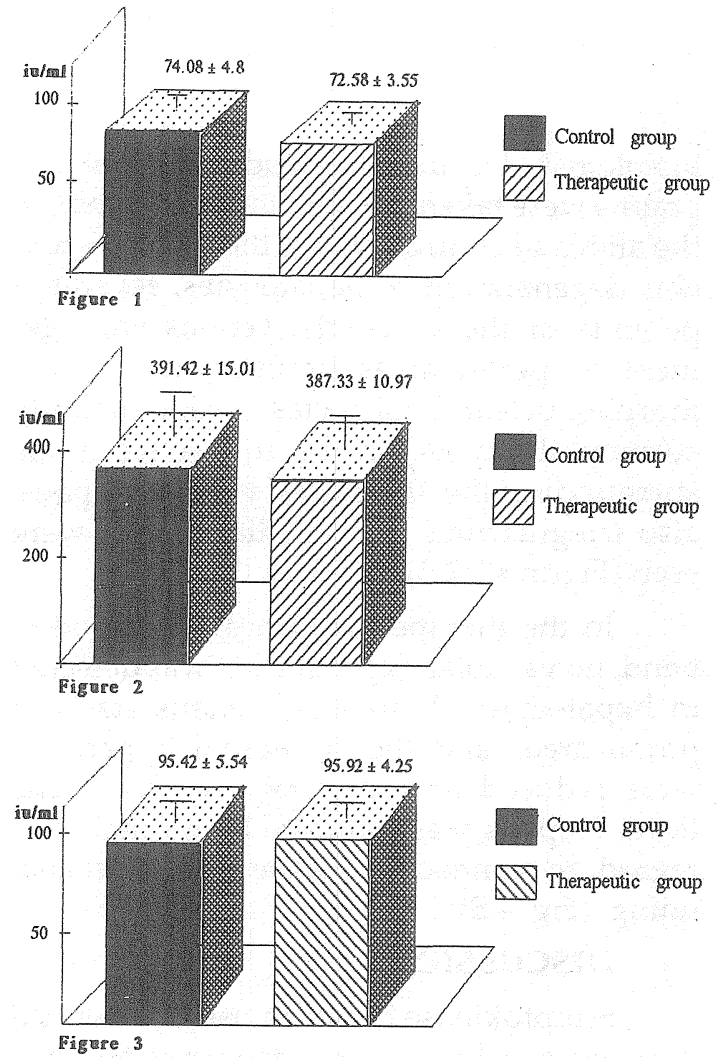

Figure 1: There is no statistical difference as compared serum Alkaline Phosphatese levels in control and therapeutic groups $(t=0.25 \mathrm{SD}=22 \quad \mathrm{p}>0.05)$

Figure 2: There is no statistical difference as compared serum SGOT levels in control and therapeutic groups $(t=0.22 \mathrm{SD}=22 \quad \mathrm{p}>0.05)$.

Figure 3 : There is no statistical difference as compared serum SGPT levels in control and therapeutic groups $(t=-0.07 \quad S D=22 \quad p>0.005)$.

peutic groups. Here as a reference for liver function tests, serum SGOT, SGPT and Alkaline Phosphatase levels were compared. The Figures on the graphics are in U/L, and statistically there was no significant difference between the data of the control and therapeutic groups ( $p>0.05)$. For the histological examination, liver tissue samples were fixed. by neutral formalin solutions of $10 \%$. Following the paraffin blocking, slices of sixmicron thickness were taken off. Then the slides were examined under the light microscope by double blind method by the same 
histologist. During the study microphotographs were taken as well. It was seen that, in the slides of control group, there were vacuolar degeneration of hepatocytes, severehyperemia of the sinusoids, venous engorgement at portal areas, infiltration of polymorphonuclear Leucocytes (predominantly eosinophilic types) in the connective tissue surrounding the structures at porta hepatis, also irregularities in epithelial linings were seen (Figures 1,2,3).

In the therapeutic group, on the other hand, no vacuolar degeneration was detected in hepatocytes. Moreover, venous stasis at portal areas and the sinosoidal hyperemia were reduced or completely resolved. The Porta Hepatis was found to be normal with regard to connective tissue and epithelial lining. (Fig. 4,5)

\section{DISCUSSION}

Streptokinase has been used for several years especially in myocardial infarction and peripheral arterial thromboembolism (4). Portal vein thrombosis, in the newborn, generally develops secondary to septic thrombophlebitis of the umbilical vein. In adults, however even if it could occur spontaneously due to thrombosis of portal, hepatic, splenic and superior mesenteric veins, it is often due to cirrhosis (5).

Following liver transplantation, acute arterial thrombosis results in infarctions in hepatobiliary tree and paranchima $(6,7)$. Similarly, portal vein thrombosis following transplantation, is also a serious and lethal complication (8). Progressive hepatic insufficiency develops, is followed by rapid ascit formation and results in death $(6,7)$.

In general, for such severe and lethalconditions, there is no time for surgical interference nor the clinical feature of the patient may allow such a procedure. We planned, in our study, to go over such a problem. In this experimental study, we have got very encouraging results, in the management of newly formed portal vein thrombo is in that, we used low-dose Streptokinase as a chocie. All the rats could survive in the postoperative days, and they were also found to be normal histologicaly and biochemicaly. Because of this, we can surely say that in early cases, direct administration of Streptokinase into the affected vascular system yields good results. We believe that, it would be an important therapeutic procedure in selected cases, for the hepatic system.

\section{REFERENCES}

1. Takada Y, Takada A. Evidence for the formation of a trimolecular complex between streptokinase, plasninogen and fibrinogen. Thrombosis Research 1989; 53 (4): 409-15

2. Ilan $Y$, Oren $R$, Shouval D, et al. Postpartum Budd-Chiari syndome with prolonged hypercoagulability state. Am J Obstet restet Gynecol 1990; 162 (5): $1164-5$

3. Koltz RL, Maki HS, Kuehner ME, et al. Induced clod Iysis by mini-dose injection of streptokinase in non-perfused arterial segments of rabbits. Thrombosis Research 1989; 53 (4): 4 01-8

4. Comeroto AJ, White JV, Grosh JD, et al. Intraoperative intaarterial thrombolytic therapy for salvage of limbs in patients with distal arterial thrombosis. Surg Gynecol Obstet 1989; 169 (4) : 283-9

5. Pritchard SL, Culham JA, Rogers PC, et al. Low-dose fibrinolytic therapy in infants. I Pediatr 1985; 106 (4): $59 \pm-8$

6. WilliamsJW. Post-transplant Hepatic Dysfunction. Hepatic Transplantation, Philadelphia W B Saunders Comp 1990; (4): 47-58

7. Willianls JW, Vera S, Peters TG, et al. Cholestatic jaundice after transplantation. Am J Surg 1986; 151: $65-9$

8. Robinson JM, Cockrell CH, Tisnado J, et al. Selective low-dose streptokinase infusion in the treatment of acute transplant renal vein thrombosis. Cardiovasc Intervent Radiol. 1986; 9 (2)):86-9 